\title{
外傷性脳損傷のリハビリテーション
}

\section{3. 急性期におけるリハビリテーション}

横浜市立大学医学部附属市民総合医療センターリハビリテーション科 菊地 尚久

外傷性脳損傷患者は片麻痺や失調症状などの身体機能障害より高次脳機能障害の方が日常 生活, 社会生活に対する影響が大きく，このため長期にわたり回復期での医学的リハビリテ ーション，社会復帰に対する社会的リハビリテーションを行なうことが必要となることが多 い.

欧米においては外傷性脳損傷患者に対するモデルシステムでの包括的なリハビリテーショ ンが施行され，その効果が報告されている. 本邦でも平成 13 年度から厚生労働省において 「高次脳機能障害支援モデル事業」が開始され，高次脳機能障害に対する問題，対応が検討さ れている.しかしながら急性期から回復期に至る一貫したシステムは未だ確立されておらず， しかも急性期病院の在院日数も減少傾向にあることから, 現状では長期間のリハビリテーシ ヨンが必要な患者においてもリハビリテーションの供与が少ない一般病院に転院する患者や 身体障害が軽度なために直接自宅退院を余儀なくされている患者が存在することが問題とな っている.

急性期外傷性脳損傷患者に対するリハビリテーションは早期離床, 麻痺の回復促進, 拘 縮・筋力低下などの二次的廃用の予防，日常生活動作の再獲得，そして高次脳機能障害の評 価・治療などが目的となる。さらにリハスタッフが合併症の治療に対する評価，リハビリテ ーションに対する評価などを基に退院時ゴール，長期的ゴールに合わせて退院後の方針につ いて検討，提示していくことも重要な役割であると考える.

また受傷時軽症であってもその後に認知・記憶障害を残す軽症脳外傷患者の報告があり, 第 3 次救急施設である当院では比率は少ないものの第 2 次救急施設に入院した患者を含める と相当数存在する可能性があり，これらの患者に対するリハビリテーションも重要と考えて いる.

ここでは急性期におけるリハビリテーションに対する評価・効果について軽症脳外傷を含 めて述べるとともに，急性期病院を退院した後に患者が適切なリハビリテーションを受ける ためにはどのようなシステム作りが必要であるかということについても検討し，報告する. 